\title{
GLOSA DO WYROKU SĄDU NAJWYŻSZEGO SYGN. AKT V CSK 709/15
}

\begin{abstract}
Streszczenie. Niniejsza glosa stanowi komentarz do orzeczeń Sądu Okręgowego i Apelacyjnego wydanych w sprawie o unieważnienie związku małżeńskiego z powództwa M. Z. przeciwko J. Z., w wyniku zawarcia go z pozwaną chorą na schizofrenię paranoidalną, która ukryła ten fakt przed przyszłym mężem. Przytoczono argumenty podające w wątpliwość słuszność rozstrzygnięcia wydanego przez Sąd I Instancji oraz zaprezentowano przesłanki potwierdzające trafność orzeczenia Sądu II Instancji.
\end{abstract}

Słowa kluczowe: schizofrenia paranoidalna, niedorozwój umysłowy, zgoda sądu na zawarcie związku małżeńskiego, zawarcie związku małżeńskiego, unieważnienie małżeństwa.

\section{WPROWADZENIE}

Celem niniejszej glosy jest podjęcie istotnych rozważań w obliczu coraz częściej rozwijających się w społeczeństwie zaburzeń psychicznych, wpływających (na gruncie obowiązujących regulacji prawnych) na zdolność do zawarcia związku małżeńskiego. W ścisłej zależności tematycznej, dotyczącej wymienionej problematyki, pozostają przewidziane przepisami prawa legitymacje współmałżonków osób borykających się z problemami natury psychicznej do wniesienia powództwa o unieważnienie zawartego związku małżeńskiego. Są one także przedmiotem analizy w niniejszym artykule.

Niewątpliwie zaburzenia psychiczne ze względu na swoją różnorodność i coraz większą częstotliwość występowania stanowią wielowymiarowy problem społeczny. Dysfunkcje w zakresie zdrowia psychicznego wpływają na funkcjonowanie zawodowe, osobiste i społeczne jednostki nimi dotkniętej oraz poważnie je utrudniają. Mając na uwadze powyższe dane, polski ustawodawca podczas tworzenia obowiązujących regulacji prawnych był zobligowany do uwzględnienia w nich wszystkich obszarów życia osób cierpiących na zaburzenia psychiczne. Odnosi się to także do możliwości zawierania przez nich związków małżeńskich i ewentualnych przesłanek warunkujących legitymację do wniesienia powództwa o ich unieważnienie. Dobrym przykładem dla omówienia obowiązujących

${ }^{*}$ Uniwersytet Łódzki, Wydział Prawa i Administracji, Katedra Prawa Karnego, Zakład Nauki o Przestępstwie, anna.lisowska@unilodz.eu. 
regulacji prawych w rozważanym zakresie jest wyrok Sądu Najwyższego z dnia 29 września 2016 r., sygn. akt V CSK 709/15, wydany w odniesieniu do uprzednio orzeczonych w sprawie orzeczeń Sądu Okręgowego i Sądu Apelacyjnego.

\section{STAN FAKTYCZNY}

W dniu 29 września 2016 r. Sąd Najwyższy po rozpoznaniu sprawy na rozprawie w Izbie Cywilnej z powództwa M. Z. przeciwko J. Z. o unieważnienie małżeństwa oddalił skargę kasacyjną pozwanej od wyroku Sądu Apelacyjnego z dnia 18 czerwca 2015 r. i nie obciążył pozwanej kosztami postępowania kasacyjnego.

Sąd Okręgowy w K. w dniu 17 października 2011 r. oddalił wyrokiem powództwo M. Z. przeciwko J. Z. o unieważnienie małżeństwa. Z poczynionych w drodze postępowania sądowego ustaleń faktycznych wynika, że związek małżeński pomiędzy M. Z. i J. Z. został zawarty przez strony kierujące się miłością w dniu 13 listopada 2010 r., a z zawartego małżeństwa nie zrodziło się potomstwo. Przed zawarciem związku małżeńskiego strony spotykały się ze sobą przez półtora roku. J. Z. w chwili wstąpienia w związek małżeński chorowała na schizofrenię paranoidalną, będącą w tym czasie w fazie remisji. Powód i pozwana, trwając ze sobą we wspólnocie małżeńskiej, pozostawali zgodni do marca 2011 r. W tym czasie w zachowaniu J. Z. zaczęto obserwować niepokojące sygnały. Zgłaszała ona pojawiające się u niej trudności w pracy i problemy z koncentracją. Dolegliwości żony powód łączył ze stresem i zmianą przez nią miejsca zamieszkania. Za przyzwoleniem J. Z., M. Z. zapisał ją na wizytę lekarską. Do terminu umówionej wizyty stan zdrowia J. Z. uległ pogorszeniu. Pozwana wykazywała objawy stanu depresyjnego, odczuwała lęk, płakała, a jej wypowiedzi nie były racjonalne. W trakcie wizyty lekarskiej M. Z. został poinformowany przez lekarza, że jego żona choruje na schizofrenię paranoidalną. Zgodnie $\mathrm{z}$ własną wolą, od tego momentu J. Z. powróciła do domu rodzinnego, w którym przebywa. Powód i pozwana, mimo kilkukrotnych spotkań, nie powrócili ze sobą do wspólnego pożycia małżeńskiego. Z powodu nasilającej się niezgody między stronami wynikłej na podłożu choroby psychicznej J. Z., powód i pozwana jednoznacznie przestali się ze sobą kontaktować. W związku z decyzją pozwanej o podjęciu terapii i leczenia farmakologicznego, występująca $u$ niej schizofrenia paranoidalna jest $\mathrm{w}$ fazie remisji. M. Z., zawierając związek małżeński z J. Z. w dniu 13 listopada 2010 r., nie był świadomy, że pozwana od 2006 r. cierpi na chorobę psychiczną, na którą, przed wstąpieniem z nim w związek małżeński, leczyła się w zakładzie psychiatrycznym w T. Powód, przed zawarciem związku małżeńskiego z J. Z., asystował pozwanej w jej wizytach u lekarza psychiatry. Nie miał jednak świadomości, że pozwana choruje na schizofrenię paranoidalną, ponieważ konieczność wizyt u lekarza psychiatry wyjaśniała ona przebytym załamaniem nerwowym. 
Bazując na zgromadzonych w toku postępowania sądowego ustaleniach faktycznych, Sąd Okręgowy w K. uznał, że nie zachodziły przesłanki do unieważnienia związku małżeńskiego zawartego pomiędzy M. Z. i J. Z. w dniu 13 listopada 2010 r. Organ wymiaru sprawiedliwości odniósł zgromadzony materiał dowodowy do przesłanek warunkujących unieważnienie małżeństwa, wskazanych w art. $12 \S 1$ zd. 2 k.r.o., zgodnie z którymi ,[...] Jeżeli jednak stan zdrowia lub umysłu takiej osoby nie zagraża małżeństwu ani zdrowiu przyszłego potomstwa i jeżeli osoba ta nie została ubezwłasnowolniona całkowicie, sąd może jej zezwolić na zawarcie małżeństwa" (ustawa z dnia 25 lutego 1964 r. Kodeks rodzinny i opiekuńczy, Dz. U. 1964, Nr 9, poz. 59, art. 12 § 1 zd. 2), a także stwierdził, że ,[...] choroba pozwanej, jeżeli jest prawidłowo leczona nie zagraża małżeństwu i nie zagrażała mu w chwili jego zawarcia. Leczenie choroby połączone ze wsparciem rodziny, psychoedukacją i wzajemnym wsparciem małżonków i wzajemnym zaufaniem pozwala uniknąc rzutów chorobowych i umożliwia nawiązanie normalnych relacji małżeńskich" (wyrok SN, sygn. akt V CSK, 709/15). Co więcej, Sąd Okręgowy nie odrzucił prawdopodobieństwa powrotu powoda i pozwanej do siebie celem prowadzenia przez nich wspólnego życia małżeńskiego. Zauważył ponadto, że choroba psychiczna, na którą cierpi J. Z., nie stanowi zagrożenia dla zdrowia jej przyszłych dzieci. Sąd Okręgowy powołał się na okoliczność, że niebezpieczeństwo dziedziczenia schizofrenii paranoidalnej przez potomstwo chorego nie jest bezsprzecznie udowodnione, niezależnie od tego, że dzieci osoby cierpiącej na chorobę psychiczną obarczone są większym ryzykiem zachorowania na nią niż pozostała część społeczeństwa wywodząca się od zdrowych rodziców. Zauważył również, że stan remisji choroby, na którą cierpi J. Z., nie pozostaje w sprzeczności z właściwym wykonywaniem przez nią obowiązków wynikających z ciążącej na rodzicu władzy rodzicielskiej i wychowywaniu przyszłego potomstwa odpowiednio do społecznie uznanych reguł. Biorąc pod uwagę wszystkie przytoczone argumenty, ,Sąd Okręgowy uznał, że unieważnienie małżeństwa stron tylko z powodu choroby psychicznej pozwanej byłoby drastycznym pozbawieniem jej podstawowych praw obywatelskich i wyrazem jej dyskryminacji” (wyrok SN, sygn. akt V CSK, 709/15).

M. Z. odwołał się od decyzji Sądu Okręgowego poprzez złożenie apelacji od orzeczonego wyroku. Sąd Apelacyjny w dniu 18 czerwca 2015 r. zmienił orzeczenie Sądu Okręgowego, unieważniając małżeństwo zawarte przez M. Z. i J. Z. w dniu 13 listopada 2010 r., w związku z ustaleniem, że J. Z. wstępując w związek małżeński, czyniła to w złej wierze. Sąd II Instancji wziął pod uwagę podniesiony w apelacji zarzut obrazy przepisów prawa materialnego zawartych w art. $12 \S 1$ zd. 1 k.r.o. tj. „Nie może zawrzeć małżeństwa osoba dotknięta chorobą psychiczną albo niedorozwojem umysłowym [...]" (ustawa z dnia 25 lutego 1964 r. Kodeks rodzinny i opiekuńczy, Dz. U. 1964, Nr 9, poz. 59, art. 12 § 1 zd. 1), stojąc na stanowisku, że choroba psychiczna pozwanej spełniała przesłankę warunkującą niedopuszczalność zawarcia związku małżeńskiego, wpływającą na właściwe 
funkcjonowanie związku małżeńskiego i zdrowie przyszłego potomstwa. Dla podjętej przez Sąd Apelacyjny decyzji, wyrażonej w wydanym w dniu 18 czerwca $2015 \mathrm{r}$. wyroku, istotne znaczenie miały wzajemne relacje występujące pomiędzy M. Z. i J. Z. Na podstawie opinii biegłych zauważono, że będąca w fazie remisji choroba J. Z. nie stwarza niebezpieczeństwa dla prawidłowego funkcjonowania małżeństwa ani dobra potencjalnych dzieci pary. W fazie remisji choroby J. Z. ,[...] jest zdolna do budowania pełnowartościowych, prawidłowych relacji uczuciowych, seksualnych, życiowych z mężem i macierzyńskich z dziećmi oraz wartościowego kształtowania ich rozwoju intelektualnego i osobowościowego" (wyrok SN, sygn. akt V CSK, 709/15). Jak zauważył Sąd Apelacyjny, Sąd I Instancji wydając wyrok, nie wziął pod uwagę, że w sytuacji pogorszenia stanu zdrowia psychicznego pozwanej w wyniku zaostrzenia objawów jej choroby może ona stać się w tym czasie niezdolną do wypełniania ciążących na żonie obowiązków małżeńskich i rodzicielskich w wypadku posiadania przyszłego potomstwa. Co więcej, Sąd II Instancji zaznaczył, że należy wziąć pod uwagę ryzyko pogorszenia stanu zdrowia psychicznego J. Z. w związku z chorobą psychiczną, której doświadcza. Biorąc pod uwagę wzajemne relacje pomiędzy powodem i pozwaną oraz nieświadomość M. Z. o chorobie psychicznej J. Z., Sąd Apelacyjny stwierdził, że dalsza kontynuacja zawartego między stronami związku małżeńskiego jest niemożliwa. Sąd II Instancji odniósł się także do wywodów Sądu Okręgowego stwierdzających, że ,[...] osoby chore na schizofrenię funkcjonują prawidłowo w związkach z partnerami oferującymi im wsparcie, akceptującymi fakt i rodzaj choroby, zdolnymi fizycznie i psychicznie stawić czoła ewentualnym trudnym sytuacjom w pożyciu na skutek zaostrzenia choroby współmałżonka [...]" (wyrok SN, sygn. akt V CSK, 709/15) i uznał je za niewłaściwe w odniesieniu do relacji panujących między stronami. Co ważne, Sąd Apelacyjny podkreślił, że ciąża dla pozwanej stanowiłaby szczególny okres nie tylko ze względu na oczekiwane potomstwo, ale konieczność zachowania przez nią szczególnej staranności w procesie farmakoterapii, która z jednej strony nie zagrażałaby życiu i zdrowiu nienarodzonego dziecka, a z drugiej - nie spowodowałaby nawrotu dolegliwości w zakresie zdrowia psychicznego. Sąd II Instancji zauważył, że w czasie ciąży szczególnie ważne jest, aby przyszła matka unikała sytuacji stresowych, co w zaistniałym stanie faktycznym mogłoby być wątpliwe z uwagi, że stresorem dla pozwanej mogłaby być jej świadomość obaw współmałżonka o zdrowie psychiczne spłodzonego potomstwa i zdolności do zapewnienia mu przez nią odpowiedniej opieki i wychowania ze względu na jej chorobę. Sąd Apelacyjny uznał w przedstawionej sprawie, że J. Z. wstępując w związek małżeński, działała w złej wierze, ponieważ nie wystąpiła wcześniej o zezwolenie na jego zawarcie, a ponadto nie poinformowała męża, iż choruje na schizofrenię paranoidalną. W omawianym stanie faktycznym Sąd właściwy do rozpatrzenia apelacji wystąpił z pytaniem prawnym do Trybunału Konstytucyjnego ,[...] o zgodność art. $12 \S 1$ i 2 k.r.o. z art. 18, art. 31 ust. 1 i 3 oraz art. 47 Konstytucji z art. 14 Konwencji o ochronie 
praw człowieka i podstawowych wolności, sporządzonej w Rzymie dnia 4 listopada 1950 r. (Dz. U. z 1993 r., Nr 61, poz. 284 ze zm.) oraz z art. 12 ust. 2 i art. 23 ust. 1a Konwencji o prawach osób niepełnosprawnych, sporządzonej w Nowym Jorku dnia 13 grudnia 2006 r. (Dz. U. z 2012 r., poz. 1169)" (wyrok SN, sygn. akt V CSK, 709/15). Trybunał Konstytucyjny w związku z niedopuszczalnością wydania wyroku umorzył postępowanie postanowieniem z dnia 4 listopada 2015 r., a Sąd Apelacyjny uznał, że kontrola konstytucyjności obowiązujących regulacji prawnych pod względem ich bezpośredniego stosowania Ustawy Zasadniczej nie leży w jego właściwości.

J. Z. odwołała się od wyroku Sądu Apelacyjnego poprzez wniesienie kasacji do Sądu Najwyższego. W skardze kasacyjnej pozwana podniosła zarzut naruszenia przepisów prawa zawartych w art. 12 \$ 1 k.r.o. w związku z art. 8 ust. 2 Konstytucji. Skarżąca uzasadniała, że orzeczenie Sądu Apelacyjnego zostało wydane wskutek błędnego zastosowania przepisów prawa. Ponadto podnosiła, że w toku postępowania odwoławczego przed Sądem II Instancji nie dokonano prawidłowej subsumcji stanu faktycznego, w wyniku czego poczyniono inne, lecz błędne ustalenia do tych podjętych przez Sąd Okręgowy. W skardze kasacyjnej J. Z. powoływała się na art. 23 k.r.o., zgodnie z którym małżonkowie są zobowiązani do udzielania wzajemnej pomocy, wierności i wspólnego podejmowania działań dla dobra rodziny. Pozwana powołała się także na przekroczenie przez Sąd II Instancji ram wynikających z art. 233 k.p.c. J. Z. w skardze kasacyjnej wnosiła ,[...] o uchylenie zaskarżonego wyroku i orzeczenie co do istoty sprawy przez oddalenie apelacji powoda i obciążenie go kosztami postępowania za wszystkie instancje" (wyrok SN, sygn. akt V CSK, 709/15). Sąd Najwyższy po zapoznaniu się z wniesioną przez J. Z. skargą kasacyjną i ustaleniu, że nie zawiera ona uzasadnionej podstawy, oddalił ją w dniu 29 września 2016 r., nie obciążając pozwanej kosztami postępowania kasacyjnego.

\section{OCENA ROZSTRZYGNIĘĆ SĄDÓW I I II INSTANCJI ZAPADEYCH W SPRAWIE}

Analizę orzeczonych przez Sąd Okręgowy i Sąd Apelacyjny rozstrzygnięć w omawianym stanie faktycznym należałoby rozpocząć od przeglądu regulacji prawnych znajdujących dla nich zastosowanie. Art. $12 \S 1$ k.r.o. stanowi, że „Nie może zawrzeć małżeństwa osoba dotknięta chorobą psychiczną albo niedorozwojem umysłowym. Jeżeli jednak stan zdrowia lub umysłu takiej osoby nie zagraża małżeństwu ani zdrowiu przyszłego potomstwa i jeżeli osoba ta nie została ubezwłasnowolniona całkowicie, sąd może jej zezwolić na zawarcie małżeństwa" (ustawa z dnia 25 lutego 1964 r. Kodeks rodzinny i opiekuńczy, Dz. U. 1964, Nr 9, poz. 59, art. $12 \S 1$ ). Bez wątpienia przytoczony przepis prawa odnosi się do okoliczności zawarcia związku małżeńskiego przez strony omawianego postępowania, 
co potwierdzają poczynione w jego toku ustalenia stanu faktycznego i wydane na ich podstawie przez instytucje wymiaru sprawiedliwości orzeczenia. Na uwagę zasługuje jednak to, że rozstrzygnięcia Sądu Okręgowego i Sądu Apelacyjnego, w oparciu o te same okoliczności, zostały wydane na podstawie odmiennych kwalifikacji prawnych. Sąd I Instancji, rozstrzygając sprawę, powołał się na art. 12 § 1 zd. 2 k.r.o., natomiast Sąd Apelacyjny jako podstawę prawną orzeczenia wskazał art. $12 \S 1$ zd. 1 k.r.o. Odrębne kwalifikacje prawne będące podstawą wydawanych przez sąd orzeczeń mają znaczenie nie tylko z uwagi na konsekwencje z nich wynikające, lecz także ze względu na interpretacje stanu faktycznego pozwalającego na ich zastosowanie. Interpretacja okoliczności sprawy pozwalająca na zastosowanie przez Sąd Okręgowy art. $12 \S 1$ zd. 2 k.r.o., stanowiącego podstawę oddalenia powództwa M. Z. przeciwko J. Z. o unieważnienie małżeństwa może wzbudzać pewne wątpliwości. Obowiązujące regulacje normatywne wprowadzają zakaz zawierania związków małżeńskich przez osoby dotknięte chorobą psychiczną lub niedorozwojem umysłowym, jednocześnie dopuszczając możliwość wstąpienia przez nie w związek małżeński po uzyskaniu zgody sądu, w sytuacji gdy ich stan zdrowia lub umysłu nie zagraża małżeństwu ani zdrowiu przyszłego potomstwa, a wspomniane jednostki nie zostały ubezwłasnowolnione całkowicie. Pozwana, mimo iż $\mathrm{w}$ chwili zawierania związku małżeńskiego była $\mathrm{w}$ fazie remisji objawów chorobowych, od 2006 r. cierpiała na schizofrenię paranoidalną, o czym nie poinformowała przyszłego małżonka. Nie wystąpiła również do właściwego sądu o uzyskanie zgody na wstąpienie w związek małżeński. W tym miejscu można jednak podnieść, że J. Z. mogła nie być świadoma konieczności uzyskania owej zgody. Należałoby się jednak zgodzić, że wiedza osoby chorej psychicznie lub dotkniętej niedorozwojem umysłowym nie wydaje się mieć większego znaczenia dla konieczności uzyskania od organu wymiaru sprawiedliwości zezwolenia na ślub. Przed zawarciem związku małżeńskiego nupturienci zobowiązani są do spełnienia szeregu wymogów formalnych. Wątpliwe wydaje się zaistnienie sytuacji, w której nie zostaliby oni poinformowani o przeszkodach uniemożliwiających zawarcie związku małżeńskiego, zwłaszcza, że składają kierownikowi urzędu stanu cywilnego pisemne zapewnienie, że nie wiedzą o istnieniu okoliczności wyłączających zawarcie małżeństwa (ustawa z dnia 25 lutego 1964 r. Kodeks rodzinny i opiekuńczy, Dz. U. 1964, Nr 9, poz. 59, art. 4). Ponadto powszechnie przyjmuje się, że obywatele Rzeczypospolitej Polskiej zobowiązani są do znajomości obowiązujących przepisów prawa i ich przestrzegania. Co więcej, dolegliwość w zakresie zdrowia psychicznego J. Z. powszechnie uznawana jest za poważną. Schizofrenia paranoidalna, którą zdiagnozowano u pozwanej, zaliczana jest do grupy zaburzeń psychotycznych, odznaczających się obecnością symptomów zarówno pozytywnych, jak i negatywnych związanych z występowaniem licznych trudności w różnych obszarach funkcjonowania jednostki, np. w pracy, nauce, tworzeniu i podtrzymywaniu przez nią relacji interpersonalnych czy chociażby dbaniu o siebie (Shahrokh, Hales 2009, 161). Zgodnie z art. $12 \S 1$ k.r.o. powinno 
się przyjąć, że J. Z. jako osoba ze zdiagnozowaną u niej w 2006 r. schizofrenią paranoidalną, zaliczaną do grupy psychoz, a tym samym chorób psychicznych, nie była zdolna w świetle obowiązujących przepisów prawa do wstąpienia w dniu 13 listopada 2010 r. w związek małżeński bez wcześniejszej zgody sądu. Wypada zauważyć, że bez znaczenia pozostaje fakt, iż w chwili wstąpienia w związek małżeński pozwana była w fazie remisji swojej choroby. Co prawda w doktrynie podnosi się wątpliwości co do możności zawarcia związku małżeńskiego w stanie remisji choroby, jednak podkreśla się, że każdorazowo nie można uznać, iż jest on tożsamy z brakiem choroby (Zielonacki 2013). O tym, czy dolegliwości w zakresie zdrowia psychicznego poprzedzające czas ustąpienia symptomów zaburzenia można uznać za chorobę psychiczną w rozumieniu art. $12 \S 1$ k.r.o., która uniemożliwia zawarcie związku małżeńskiego, za każdym razem zależy od indywidualnych czynników (Zielonacki 2013). W piśmiennictwie wskazuje się, że jeżeli warunki umożliwiają założenie, iż stan zdrowia jednostki uległ poprawie w takim stopniu, aby jej zachowanie i psychikę można było uznać za nieodbiegającą od tych właściwych dla przeciętnej osoby, a co więcej uzasadnione jest przyjęcie, że osiągnięta przez nią kondycja psychiczna nie ulegnie pogorszeniu, to błędnym byłoby wnioskowanie, że to, co nauka określa stanem remisji, jest równoznaczne z chorobą psychiczną uniemożliwiającą zawarcie związku małżeńskiego (Zielonacki 2013). Ze względu na powagę schorzenia, jakim jest schizofrenia paranoidalna i spektrum objawów jej towarzyszących, a także konieczność spełnienia kryteriów warunkujących jej rozpoznanie, dyskusyjnym mogłoby być przyjęcie w oderwaniu od konkretnego przypadku, iż występujący w niej stan remisji jest tożsamy z opisanym powyżej. Nie można bowiem dokonać takiej oceny bez dokładnego ustalenia oraz zapoznania się z dotychczasowym przebiegiem choroby i zaczerpnięciem opinii biegłych psychiatrów posiadających wiedzę we wspomnianym zakresie. Na łamach podręcznika do psychopatologii wskazano, że schizofrenia paranoidalna może mieć charakter epizodyczny, z częściową lub pełną remisją, lub przebiegać w postaci przewlekłej (Cierpiałkowska 2015, 280). W uzasadnieniu wyroku Sądu Najwyższego, który jest przedmiotem niniejszej analizy, nie zawarto informacji o przebiegu choroby pozwanej. $Z$ uwagi na nawrót objawów choroby, mający miejsce w marcu 2011 r., można domniemać, że stan remisji choroby, w którym była zawierając związek małżeński, nie był tożsamy z tym uzasadniającym przyjęcie braku choroby psychicznej wyłączającej możliwość wstąpienia w niego. Warto jednak zauważyć, że ze względu na skomplikowaną genezę zaburzeń psychicznych stwierdzenie przez specjalistów psychiatrii z całkowitą pewnością, że dany epizod schizofrenii paranoidalnej był ostatnim, jest właściwie niemożliwe. Ponadto, jak zauważono, przeprowadzenie wielu badań nie przyniosło odpowiedzi na pytanie o przyczynę różnic dotyczącą odmienności przebiegu schizofrenii paranoidalnej (Cierpiałkowska 2015, 280). Uznać trzeba, że ocena stanu remisji, w którym była J. Z. przed i w trakcie zawierania związku małżeńskiego w odniesieniu do choroby psychicznej, na którą cierpi, co 
do tego, czy nie spełniał on przesłanek wyłączających możliwość zawarcia przez nią małżeństwa, należała do sądu.

Zezwolenie na zawarcie związku małżeńskiego udzielane jest przez sąd rejonowy w trybie nieprocesowym, na wniosek osoby cierpiącej na chorobę psychiczną lub dotkniętej niedorozwojem umysłowym (Zielonacki 2013). Sąd rejonowy właściwy ze względu na miejsce zamieszkania wnioskodawcy w zakresie udzielenia mu zezwolenia na wstąpienie w związek małżeński powinien przed podjęciem decyzji wysłuchać osobę dotkniętą chorobą psychiczną lub niedorozwojem umysłowym, a także jej potencjalnego współmałżonka oraz ich bliskich (Jędrejek 2013). Stwierdzenie przez sąd, czy choroba psychiczna lub niedorozwój umysłowy, na które cierpi wnioskodawca, nie stanowi zagrożenia dla funkcjonowania przyszłego małżeństwa oraz zdrowia i wychowania potencjalnego potomstwa, wymaga uzyskania wiadomości specjalnych. Mając to na uwadze, sąd przed wyrażeniem wspomnianemu podmiotowi zgody na wstąpienie przez niego $\mathrm{w}$ związek małżeński zobowiązany jest do uzyskania opinii biegłego lekarza, najlepiej z zakresu psychiatrii (Jędrejek 2013). Jak już wcześniej zauważono, J. Z. przed wstąpieniem w związek małżeński z M. Z. nie wystąpiła do sądu rejonowego w przedmiocie otrzymania zgody na jego zawarcie. $Z$ tego względu organ wymiaru sprawiedliwości nie miał możliwości dokonania oceny, czy choroba psychiczna pozwanej nie zagrażała trwałości wspólnoty małżeńskiej i zrodzonych w wyniku jej trwania przyszłych dzieci.

Zgodnie z obowiązującymi regulacjami prawnymi legitymacja do wniesienia powództwa o unieważnienie związku małżeńskiego z powodu choroby psychicznej lub niedorozwoju umysłowego jednego ze współmałżonków przysługuje każdemu z nich (ustawa z dnia 25 lutego 1964 r. Kodeks rodzinny i opiekuńczy, Dz. U. 1964, Nr 9, poz. 59, art. 12 § 2). Powództwo staje się jednak bezpodstawne po ustaniu choroby psychicznej jednego ze współmałżonków (ustawa z dnia 25 lutego 1964 r. Kodeks rodzinny i opiekuńczy, Dz. U. 1964, Nr 9, poz. 59, art. 12 § 3). Zauważyć należy, że ustanie choroby psychicznej męża lub żony musi nastąpić przed wydaniem rozstrzygnięcia sądu w zakresie unieważnienia związku małżeńskiego, co nie jest równoznaczne z wyleczeniem się podmiotu z dolegliwości psychicznych przed wytoczeniem powództwa (Zielonacki 2013). Analizując przedstawiony stan faktyczny, wątpliwe byłoby uznanie, że w chwili wnoszenia powództwa o unieważnienie związku małżeńskiego przez M. Z. choroba psychiczna J. Z. ustała. Można domniemać, że właśnie nawrót objawów chorobowych żony, tj. jej płaczliwość, lękliwość, nastrój depresyjny oraz ich wpływ na funkcjonowanie wspólnoty małżeńskiej był jedną z głównych przyczyn wniesienia powództwa przez M. Z. o stwierdzenie nieważności zawartego małżeństwa. $Z$ całą pewnością podczas analizy przytoczonej sprawy na myśl nasuwa się pytanie, czy J. Z. w chwili zawierania związku małżeńskiego była zdolna do dokonania tego i czy występując uprzednio do sądu, otrzymałaby zgodę na poczynienie wymienionej czynności prawnej. Nietrudno zauważyć, iż nie sposób znaleźć 
odpowiedzi w kwestii przybliżonej materii. Być może właśnie z tego względu zarówno w judykaturze, jak i doktrynie prawa rodzinnego istnieje sprzeczność w aspekcie wyrażania przez sąd zgody na zawarcie związku małżeńskiego przez osobę chorą psychicznie lub dotkniętą niedorozwojem umysłowym po uprzednim wstąpieniu przez nią w niego (Zielonacki 2013). Powinno się zauważyć, że dominujące stanowisko bazuje na możliwości osądu zawartego małżeństwa przez osobę cierpiącą na chorobę psychiczną lub niedorozwój umysłowy bez pozyskania wcześniejszej zgody instytucji wymiaru sprawiedliwości (Zielonacki 2013). W takim przypadku sąd powinien ustalić, czy w chwili dokonywania omawianej czynności prawnej istniały okoliczności zezwalające na jej dokonanie (Zielonacki 2013). W sytuacji przyjęcia ich istnienia powództwo o stwierdzenie nieważności małżeństwa ulega oddaleniu (Zielonacki 2013). Podobnie stwierdzono w tezie uchwały Sądu Najwyższego w składzie 7 sędziów, z dnia 9 maja 2002 r., sygn. akt III CZP 7/02, która brzmi ,[...] W sprawie o unieważnienie małżeństwa $\mathrm{z}$ powodu choroby psychicznej albo niedorozwoju umysłowego jednego z małżonków sąd ustala istnienie okoliczności wymienionych w art. $12 \S 1$ zdanie drugie k.r.o." (Jędrejek 2013). Na tej podstawie w analizowanej sprawie Sąd Okręgowy oddalił powództwo M. Z. przeciwko J. Z. o unieważnienie związku małżeńskiego. Wątpliwe pod względem swojej słuszności mogą być natomiast założenia Sądu I Instancji, stanowiące podstawę wydanego rozstrzygnięcia, co do tego, że choroba psychiczna J. Z., jeśli oddziałuje się na nią leczniczo, nie stwarza zagrożenia dla małżeństwa i nie była nim w chwili jego zawierania. Schizofrenia paranoidalna, na którą choruje od 2006 r. pozwana, charakteryzuje się występowaniem urojeń, wyraźnych halucynacji słuchowych i zaburzeń spostrzegania (Cierpiałkowska 2015, 279). Jak podano w Międzynarodowej Statystycznej Klasyfikacji Chorób i Problemów Zdrowotnych, ICD-10 „W schizofrenii paranoidalnej dominują stosunkowo trwałe urojenia, często paranoidalne, którym zwykle towarzyszą omamy, w szczególności słuchowe, jak również inne zaburzenia postrzegania. Zaburzenia afektu, woli i mowy, a także objawy katatoniczne albo nie występują, albo mają stosunkowo niewielkie nasilenie" (ICD-10, 216). Ponadto dla tej postaci zaburzeń psychotycznych typowe są urojenia o podłożu prześladowczym, wielkościowym, odnoszącym i zazdrości (Cierpiałkowska 2015, 279). Osoby chorujące na schizofrenię paranoidalną słyszą głosy, które wydają im polecenia lub grożą (Cierpiałkowska 2015, 279). Spotykane są przypadki, w których pacjenci zamiast głosów doświadczają bezsłownych omamów w formie trzasków, śmiechów lub szumów (Cierpiałkowska 2015, 279). Wielokrotne badania naukowe nie pozwoliły na wskazanie przyczyny decydującej o różnym przebiegu schizofrenii paranoidalnej (Cierpiałkowska 2015, 280). Mając to na względzie, ciężko zgodzić się ze stanowiskiem Sądu Okręgowego, że schizofrenia paranoidalna nie stanowi zagrożenia dla funkcjonowania małżeństwa i przyszłego potomstwa. W obliczu przytoczonych argumentów zdanie Sądu I Instancji, że „Leczenie choroby połączone ze wsparciem rodziny, psychoedukacją i wzajemnym wsparciem 
małżonków i wzajemnym zaufaniem pozwala uniknąć rzutów chorobowych i umożliwia nawiązanie normalnych relacji małżeńskich" (wyrok SN, sygn. akt V CSK, 709/15), wydaje się nie do przyjęcia, zawłaszcza że naukowo nie udało się stwierdzić przyczyn różnicujących przebieg schizofrenii paranoidalnej. Niewątpliwie, leczenie choroby, wsparcie bliskich i psychoedukacja mają wpływ na bieg schizofrenii paranoidalnej, lecz prędzej należałoby uznać, że odnoszą się do zaostrzenia lub złagodzenia jego objawów. W odniesieniu do schizofrenii na gruncie psychiatrii podaje się, że ,Znane przesłanki wskazują na patogenezę wieloczynnikową, z różnym udziałem czynników dziedzicznych i nabytych, zależnych od układu nerwowego i innych układów regulujących oraz od uwarunkowań środowiskowych" (Pużyński, Rybakowski, Wciórka 2011, 196). Przy tak zróżnicowanej genezie omawianego zaburzenia psychicznego trudno zgodzić się z założeniem, że samo leczenie, wsparcie najbliższych i psychoedukacja mogą z całą pewnością zapobiec wystąpieniu kolejnego epizodu choroby. Nie należy ponadto zapominać, że J. Z., wstępując w związek małżeński z M. Z., nie poinformowała go o swojej chorobie przez co żeniąc się z nią, nie miał świadomości, z jakimi trudnościami może przyjść mu się zmierzyć. Nie wiadomo, czy gdyby powód wiedział, że J. Z. choruje na schizofrenię paranoidalną, chciałby się z nią ożenić chociażby ze względu na poczucie swojej gotowości i ocenę zdolności co do stanowienia wsparcia dla takiej osoby. Ponadto dyskusyjne może być też stanowisko sądu, że schizofrenia paranoidalna nie zagraża zdrowiu przyszłego potomstwa ze względu na aspekt genetyczny tej choroby. Jak trafnie zauważył Sąd I Instancji, dziedziczność schizofrenii paranoidalnej nie została jednoznacznie potwierdzona, choć zwiększa ryzyko zachorowania na nią potomstwa osoby chorej w stopniu większym niż w odniesieniu do reszty ludności. Dane naukowe podają, że ryzyko zachorowania osób spokrewnionych z chorym na schizofrenię jest większe od 5 do 15 razy w zestawieniu z ogółem ludności, w zależności od stopnia pokrewieństwa lub liczby odziedziczonych genów (Pużyński, Rybakowski, Wciórka 2011, 213). Ponadto trzeba zaznaczyć, że pokrewieństwo z osobą chorą na schizofrenię wiąże się nie tyle $\mathrm{z}$ większym niebezpieczeństwem zachorowania na to zaburzenie psychiczne, ile z pewną predyspozycją do rozwinięcia się pełnego wachlarza zaburzeń charakteryzujących się ,[...] trudnościami przystosowania, cechami (schizotymia) lub zaburzeniami osobowości (cechy schizoidalne, schizotypowe, paranoiczne), a niekiedy zaburzeniami z pogranicza schizofrenii, a nawet innymi psychozami" (Pużyński, Rybakowski, Wciórka 2011, 214). Mając na uwadze wszystkie przytoczone argumenty w analizowanym stanie faktycznym, w mojej ocenie stanowisko zajęte przez Sąd Okręgowy oddalające powództwo M. Z. przeciwko J. Z. o stwierdzenie nieważności małżeństwa wydaje się błędne. Jestem zdania, że rozstrzygnięcie Sądu Apelacyjnego w tym konkretnym przypadku jest trafniejsze. Zgadzam się z ustaleniami Sądu II Instancji wskazującymi, że choć prawdą jest, że w czasie remisji osoba cierpiąca na schizofrenię paranoidalną jest zdolna do funkcjonowania niezagrażającego małżeństwu ani wycho- 
wywaniu dzieci, to jednak w stanie zaostrzenia objawów dolegliwości psychicznej spełnienie powyższych obowiązków może stać się niemożliwe lub znacznie utrudnione. Ponadto uważam, że w omawianym stanie faktycznym doniosłe znaczenie miało to, że pozwana J. Z. przed zawarciem związku małżeńskiego nie poinformowała swojego przyszłego męża o chorobie psychicznej, na którą cierpi. Budowanie tak szczególnej, bliskiej i trwałej relacji z drugą osobą na kłamstwie w tak ważnych kwestiach samo w sobie budzi wątpliwości co do sensu jej tworzenia i racji bytu. Z tego względu zgadzam się ze stanowiskiem Sądu Apelacyjnego unieważniającego małżeństwo J. Z i M. Z. jako zawarte przez pozwaną w złej wierze. Z uwagi na brak wątpliwości co do słuszności oddalenia kasacji przez Sąd Najwyższy i tym samym utrzymaniu w mocy orzeczenia Sądu Apelacyjnego, w mojej ocenie wyrok ten nie wymaga komentarza w niniejszej glosie.

\section{PODSUMOWANIE}

Przedmiot niniejszej glosy stanowił komentarz do wydanych w przytoczonym stanie faktycznym orzeczeń Sądu Okręgowego i Apelacyjnego. Poruszono w nim najważniejsze kwestie związane z zawieraniem związku małżeńskiego przez osobę cierpiącą na schizofrenię paranoidalną. Przedstawiono wątpliwości pojawiające się w związku z orzeczeniem Sądu I Instancji i poparto je stosownymi argumentami. Podobnie uczyniono, zgadzając się ze stanowiskiem Sądu II Instancji.

Komentarz do wydanych przez instytucje wymiaru sprawiedliwości orzeczeń w przedstawionym stanie faktycznym wydaje się istotny z uwagi na coraz większą liczbę osób cierpiących na różnego rodzaju zaburzenia psychiczne. Nie należy zapominać, że jednostki te zawierają związki małżeńskie i na co dzień tworzą szczęśliwe rodziny. Sam fakt cierpienia przez osobę na zaburzenie psychiczne nie determinuje braku możliwości wstąpienia przez nią w związek małżeński. Wszystko zależy od rodzaju danego zaburzenia. W przytoczonym stanie faktycznym nie tylko rodzaj zaburzenia psychicznego J. Z. determinował unieważnienie związku małżeńskiego, lecz także okoliczność, że pozwana nie poinformowała o swojej chorobie przyszłego męża. W przypadku gdyby J. Z. powiedziała mężowi o tym, że choruje na schizofrenię paranoidalną przed zawarciem małżeństwa, być może nadal decydując się na nie, nie wystąpiłby później z powództwem o jego unieważnienie. Opisana sytuacja ukazała, iż w sprawach tak szczególnie ważnych, jak zawarcie związku małżeńskiego nie warto bazować na kłamstwie. 


\section{BIBLIOGRAFIA}

Cierpiałkowska, Lidia. 2015. Psychopatologia. Warszawa: Scholar Wydawnictwo Naukowe.

Jędrejek, Andrzej. 2013. Komentarz do art. 12 Kodeksu rodzinnego i opiekuńczego. Stan prawny: 1.01.2013. http://lex.uni.lodz.pl [dostęp 19.05.2017].

Międzynarodowa Statystyczna Klasyfikacja Chorób i Problemów Zdrowotnych - X Rewizja. Tom I. Wydanie 2008. Centrum Systemów Informacyjnych Ochrony Zdrowia 2012. http://stat.gov.pl/ Klasyfikacje/doc/icd10/pdf/ICD10TomI.pdf [dostęp 21.01.2018].

Pużyński, Stanisław, Janusz Rybakowski, Jacek Wciórka. 2011. Psychiatria. Psychiatria Kliniczna. Tom 2. Wrocław: Edra Urban \& Partner.

Shahrokh, Narrriman C., Robert E. Hales. 2009. Amerykański słownik psychiatryczny. Wrocław: Elsevier Urban \& Partner.

Zielonacki, Andrzej. 2013. Komentarz do art. 12 Kodeksu rodzinnego i opiekuńczego. Stan prawny: 1.01.2013. http://lex.uni.lodz.pl [dostęp 19.05.2017].

\section{Akt prawny \\ Ustawa z dnia 25 lutego 1964 r. Kodeks rodzinny i opiekuńczy (Dz. U. 1964, Nr 9, poz. 59). \\ Orzecznictwo \\ Wyrok Sądu Najwyższego z dnia 29 września 2016 r., sygn. akt V CSK 709 /15, http://www.sn.pl/ orzecznictwo/SitePages/Baza\%20orzeczeń.aspx [dostęp 16.01.2018]. \\ Anna Lisowska \\ COMMENTARY ON THE JUDGEMENT OF THE SUPREME COURT, FILE NO. V CSK 709/15}

\footnotetext{
Abstract. This article was a commentary on the judgments of the Regional Court and Court of Appeal, issued in the case of marriage annulment brought by M. Z. against J. Z., where the defendant had suffered from paranoid schizophrenia and hid this fact from her future husband. The publication contained arguments questioning the validity of the decision issued by Court of First Instance. In addition, the article set forth premises approving of the ruling of Court of Second Instance.

Keywords: paranoid schizophrenia, mental retardation, consent of the court to get married, marriage, marriage annulment.
} 